\title{
Endocrinological Analysis of the Living-related Renal Transplantation in a Patient with Bartter's Syndrome
}

\author{
Takashi Yokoyama and Tooru Tamaki \\ Department of Nephrology, Yubari Municipal General Hospital, Hokkaido, Japan
}

Key words: Bartter's syndrome, renal transplantation, growth hormone therapy, reninangiotensin-aldosterone, prostaglandin

\section{Introduction}

In order to clarify endocrinological changes before and after living-related renal transplantation (RTx) in a patient with Bartter's syndrome (BS) and chronic renal failure (CRF), serial quantitative determinations of the renin-angiotensin-aldosterone system and 24 hour excretion of 6-ketoprostaglandin $\mathrm{F} 1 \alpha(\mathrm{PGF} 1 \alpha)$ and kallikrein were performed. It has been suggested that in this syndrome CRF rarely develops. This is the first report of a patient with BS who has undergone RTx.

\section{Case Report}

A 13 year-old male was admitted to our hospital because of pallor and short stature. He was $126 \mathrm{~cm}$ in height (M-3.8 SD) and $30 \mathrm{~kg}$ in weight (M-1.9 SD) on initial admission. Bone age was 9 years. Secondary sexual characteristics were appropriate for Tanner Stage

Correspondence: Dr. Takashi Yokoyama, Department of Nephrology, Yubari Municipal General Hospital, 6, Syako, Yubari-shi, Hokkaido 06804 Japan
I. Blood pressure was $110 / 60 \mathrm{mmHg}$, with no edema. Laboratory findings: hematocrit 22.1 $\%$, serum potassium $2.9 \mathrm{mEq} / \mathrm{L}$, sodium 137 $\mathrm{mEq} / \mathrm{L}$, chloride $103 \mathrm{mEq} / \mathrm{L}$, creatinine clearance $30.7 \mathrm{~mL} / \mathrm{min} / 1.73 \mathrm{~m}^{2}$ and elevation of $\beta 2$-microglobulin to $39.9 \mathrm{mg} / \mathrm{L}$ in the urinalysis. Arterial blood gas analysis revealed a metabolic acidosis of $\mathrm{pH} 7.333$, bicarbonate $17.3 \mathrm{mEq} / \mathrm{L}$ and base excess -7.4. Plasma renin activity (PRA) and plasma aldosterone concentration (PAC) were markedly elevated to 24.23 $\mathrm{ng} / \mathrm{mL} / \mathrm{hr}$ and $738 \mathrm{pg} / \mathrm{mL}$, respectively. 24hour urinary potassium measurement was 1.55 g/day. The insulin-like growth factor-I (IGF-I) level was $0.19 \mathrm{U} / \mathrm{mL}$ (normal:>0.2 U/mL). Peak plasma growth hormone (GH) levels after stimulation with insulin and propranolol -glucagon were 11.0 and $12.0 \mathrm{ng} / \mathrm{mL}$, respectively. The kidney biopsy specimen showed diffuse glomerulosclerosis with severe interstitial fibrosis and edema; narrowing of the small arteries and hypertrophic change of juxtaglomerular apparatus were also demonstrated. He was diagnosed as having BS with short stature and CRF. Treatment with recombinant human $\mathrm{GH}$ at $0.5 \mathrm{IU} / \mathrm{kg}$ per week for 5 years was successful and his height SD scores 


\section{Yokoyama et al.}

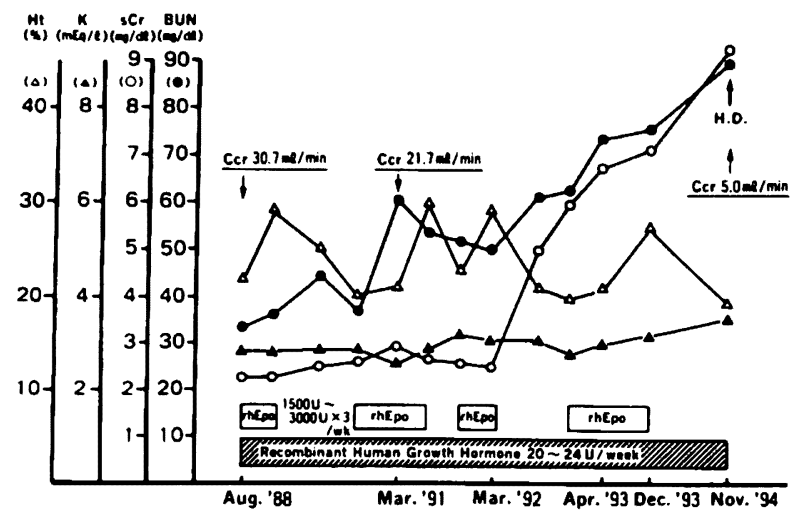

Clinical course from initial admission to induction of HD

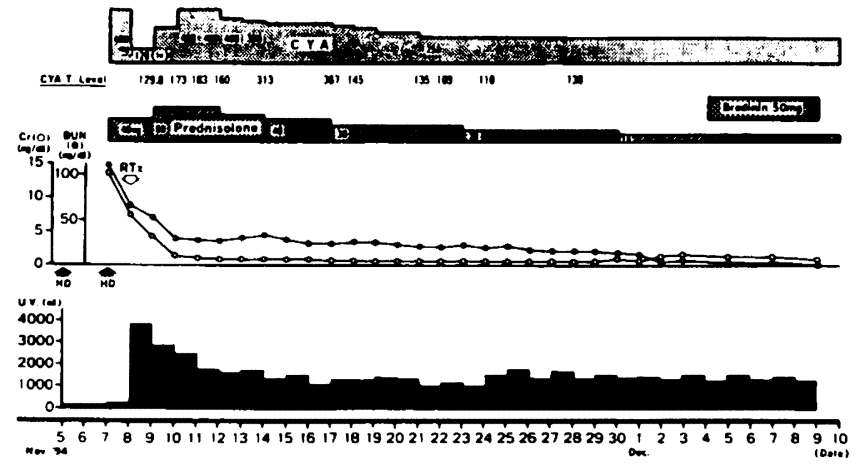

Clinical Course before and after RTx

Fig. 1 Clinical course

were significantly improved from -3.8 to -1.8 (Fig. 1). He was also treated with recombinant human erythropoietin (Epo) and the anemia improved. At the age of 18 , he began hemodialysis and he underwent RTx donated from his mother in the next year. His clinical course from initial admission to RTx are summarized in Fig. 1. PRA, angiotensin I, II (AT- I, II) and PAC were markedly changed from 37.8 to 2.3 $\mathrm{ng} / \mathrm{mL} / \mathrm{hr}, 2,400$ to $220 \mathrm{pg} / \mathrm{mL}, 256$ to $17 \mathrm{pg} / \mathrm{mL}$ and 3,700 to $110 \mathrm{pg} / \mathrm{mL}$, respectively. Urine $\mathrm{PGF}_{1} \alpha$ and kallikrein were also improved (Table 1). An AT- II loading test revealed that an infusion rate of $100 \mu \mathrm{g} / \mathrm{kg} / \mathrm{min}$ was neces-

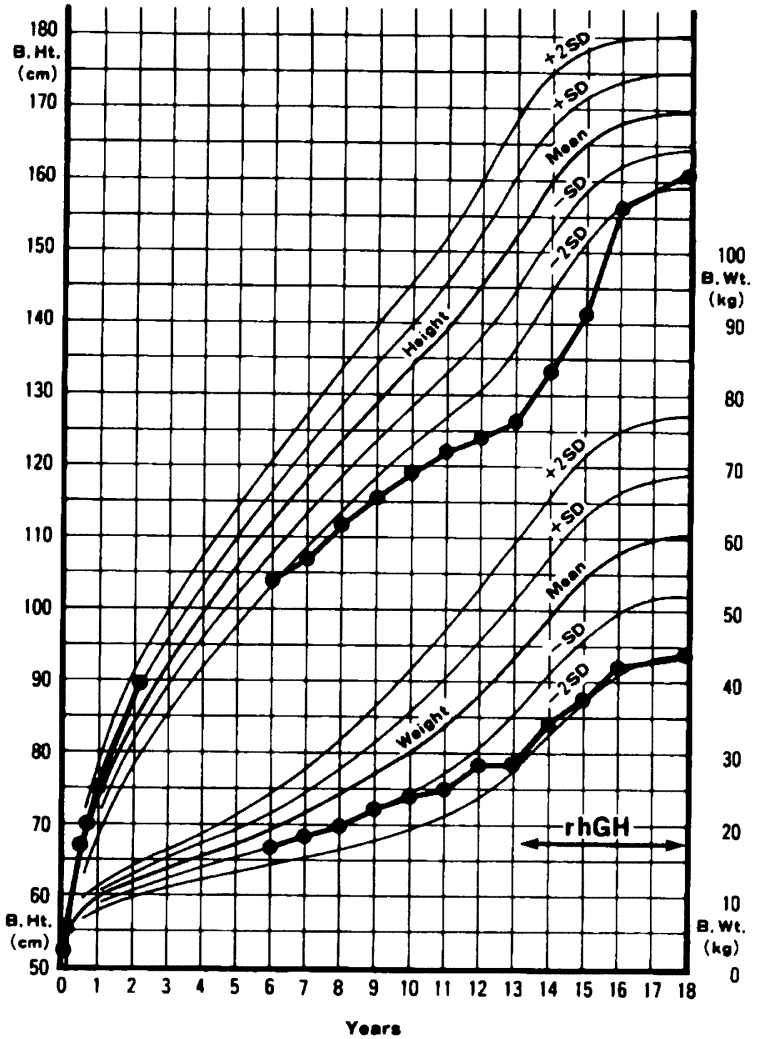

Growth chart sary to increase the systolic and diastolic pressure by $20 \mathrm{mmHg}$ before RTx. On the contrary, $20 \mu \mathrm{g} / \mathrm{kg} / \mathrm{min}$ was enough to increase both blood pressures by $20 \mathrm{mmHg}$ after RTx (Fig. 2).

\section{Discussion}

Simopolos and Bartter(1) reported that growth retardation had often been seen in BS. The role of $\mathrm{GH}$ in the growth retardation of $\mathrm{BS}$ is not known. Our patient had relatively low peak levels of $\mathrm{GH}$ to insulin and propranolol-glucagon and a low IGF-I level sug- 


\section{Renal Transplantation in Batter's Syndrome}

Table 1 Serial quantitative determinations of several hormones before and after RTx

\begin{tabular}{|c|c|c|c|c|c|c|c|c|c|c|}
\hline & $\begin{array}{c}\text { PRA } \\
(n g / m l / h r)\end{array}$ & $\begin{array}{c}\text { AT· I } \\
(p g / m l)\end{array}$ & $\begin{array}{c}\text { AT-Il } \\
(\mathrm{pg} / \mathrm{ml})\end{array}$ & $\begin{array}{c}\text { PAC } \\
(\mathrm{pg} / \mathrm{ml})\end{array}$ & $\begin{array}{c}\text { Bradykinin } \\
(p g / m l)\end{array}$ & $\begin{array}{c}\text { U-Kallikrein } \\
\text { (ug/day) }\end{array}$ & $\begin{array}{l}\text { U-PGF } 1 \alpha \\
\text { (ng/day) }\end{array}$ & $\begin{array}{l}|G F-| \\
(U / m \mid)\end{array}$ & $\begin{array}{c}\text { Epo } \\
(\mathrm{mU} / \mathrm{ml})\end{array}$ & $\begin{array}{c}u-\beta_{2} M G \\
(m g / 1)\end{array}$ \\
\hline Initial Adm. & 24.23 & 2020 & 139 & 739 & 25.0 & 410 & 860 & 0.19 & 19.9 & 39.9 \\
\hline Before $\mathbf{R T}_{\mathrm{x}}$ & 37.80 & 2400 & 256 & 3700 & & 400 & 860 & 0.17 & 16.8 & 42.5 \\
\hline After $\mathbf{R T}_{\mathbf{x}}$ & 19.37 & 1540 & 148 & 1600 & & & & & & \\
\hline After $\mathrm{RT}_{\mathrm{x}}$ (1 day) & 7.04 & 570 & 26 & 1100 & & 11.2 & 338 & & & \\
\hline After $\mathbf{R T}_{\mathrm{x}}$ ( 6 days) & 2.75 & 340 & 15 & 530 & & 12.6 & 438 & & & \\
\hline After $\mathbf{R} \mathbf{T}_{x}$ (14 days) & 2.31 & 220 & 17 & 110 & 17.0 & 25.2 & 321 & 0.19 & & \\
\hline After $R T_{x}$ ( 67 days) & 1.50 & 240 & 18 & 26 & 11.2 & & & & 15.4 & 2.1 \\
\hline Donor & 0.60 & 250 & 15 & 72 & 18.0 & 12.0 & 455 & & & \\
\hline Normals & $0.5-2.3$ & $500<$ & $9-47$ & $35-240$ & $9.6-21.0$ & $28-220$ & $125-620$ & $0.20<$ & $12.5-35.4$ & $1.0>$ \\
\hline
\end{tabular}

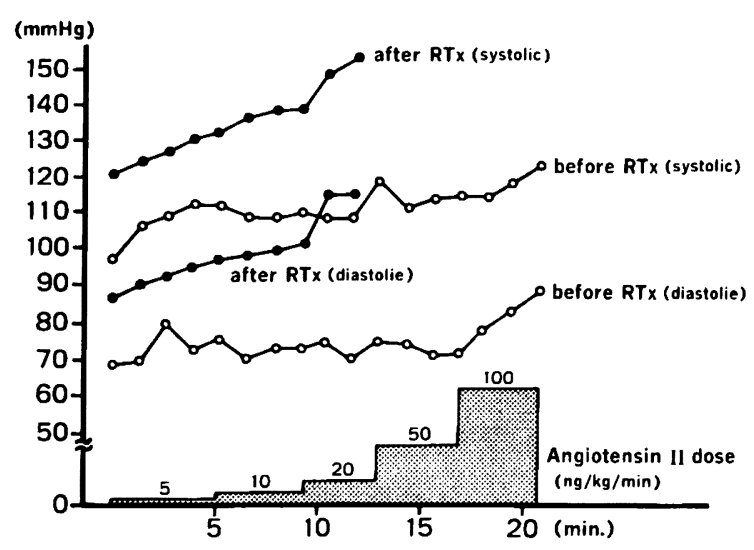

Fig. 2 Effect of angiotensin $I I$ infusion test in doses from 5 to $100 \mathrm{ng} / \mathrm{mL} / \mathrm{min}$ before and after RTx.

gested insufficient spontaneous GH secretion. Recently Boer and Zoppi(2) decribed a case of BS treated with GH in which catch-up growth occurred.

It had been suggested that BS cases rarely develop CRF. Rudin(3) described a review of 28 patients with BS followed for 10 years and only one case developed CRF. Sato(4) also reported a case of this syndrome with gradual CRF. In this case renal biopsy was performed four times and gradual increase in glomerulosclerosis, interstitial fibrosis and narrowing of the small arteries were demonstrated and arterial blood gas analysis changed from metabolic alkarosis to acidosis in proportion to the progression of renal failure. In our case metabolic acidosis had already been shown on initial admission because the patient had devolved renal failure.

As the grafted kidney fully performed hormonal regulation, abnormalities of several hormones characterized in BS could be normalized and a remarkable improvement of the AT- II loading test was also obtained.

From these results it can be deduced that the kidney plays an important role in the endocrinological pathogenesis of this syndrome. 


\section{References}

1. Simopolos AP, Bartter FC. Growth characteristics and factors influencing growth in Bartter's syndrome. J Pediatr 1972; 81:56-65.

2. Boer LA, Zoppi G. Bartter's syndrome with impairment of growth hormone secretion. Lancet 1992; 340: 860.

3. Rudin A. Bartter's syndrome. A Review of 28 Patients Followed for 10 Years. Acta Med Scand 1988; 224:165-71.

4. Sato K, Ogata M. A patient with chronic renal failure due to Bartter's syndrome. Jpn J Nephrol 1995; 37: 404-9. (in Japanese) 